\title{
Heterothallic Phytophthora: Evidence for Hormonal Regulation of Sexual Reproduction
}

\author{
By W. H. KO \\ Department of Plant Pathology, University of Hawaii, \\ Beaumont Agricultural Research Center, Hilo, Hawaii 96720, U.S.A.
}

(Received 6 January 1978)

Both $\mathrm{A}^{1}$ and $\mathrm{A}^{2}$ mating types of Phytophthora cinnamomi, Phytophthora parasitica and Phytophthora palmivora formed oospores by selfing when they were paired with different mating types on opposite sides of polycarbonate membranes. The selfing of one mating type in the presence of the other mating type demonstrates the production of diffusible substances like plant hormones as found in related fungi. Young cultures and $\mathrm{A}^{2}$ isolates were better hormone producers, whereas old cultures and $\mathrm{A}^{1}$ isolates were more responsive to hormones in both intra- and interspecific pairings. The polycarbonate membrane method should facilitate identification and genetic studies of heterothallic species of Phytophthora.

\section{INTRODUCTION}

Heterothallic species of Phytophthora readily produce oospores when two compatible types of the same species or of different species are paired in cultures (Smoot et al., 1958; Savage et al., 1968; Haasis \& Nelson, 1963). Two early reports (Galloway, 1936; Kouyeas, 1953) provided data supporting the mechanism of chemical stimulation of oospore formation originally proposed by Ashby (1929). However, subsequent efforts to confirm these results using similar and different techniques have not been successful (Stamps, 1953; Apple, 1959; Haasis \& Nelson, 1963; Marx et al., 1965; Brasier, 1972; Chang, Shepherd \& Pratt, 1974). Indirect evidence suggesting the involvement of stimulatory substances in sexual reproduction of heterothallic species of Phytophthora includes: (i) induction of oospore formation in $\mathrm{A}^{2}$ isolates of Phythophthora species by Trichoderma viride (Brasier, 1971) and T. koningii (Pratt et al., 1972); (ii) stimulation of sexual reproduction of Phytophthora parasitica by a soil bacterium (Mukerjee \& Roy, 1962); and (iii) stimulation of oospore formation in an $\mathrm{A}^{2}$ isolate of Phytophthora cinnamomi by an extract of avocado roots (Zentmyer, 1952; Ho \& Zentmyer, 1977). I report here direct evidence for hormonal regulation of oospore formation by compatible isolates of three heterothallic species of Phytophthora.

\section{METHODS}

Organisms. Species of Phytophthora used were $P$. cinnamomi (UCR97, $\mathrm{A}^{1}$ and 64F, $\mathrm{A}^{2}$ ), $P$. parasitica ( $\mathrm{P} 991$, $\mathrm{A}^{1}$ and $\mathrm{P} 731, \mathrm{~A}^{2}$ ), and $P$. palmivora (P611, $\mathrm{A}^{1}$ and $\mathrm{P} 255, \mathrm{~A}^{2}$ ). All isolates were supplied by G. A. Zentmyer with the exception of $64 \mathrm{~F}$ which was isolated from a macadamia root in Hawaii. The opposite mating types of heterothallic Pythium splendens (no. 117 and no. 461) were obtained from M. Aragaki.

Mating. Both $\mathrm{A}^{1}$ and $\mathrm{A}^{2}$ isolates of $P$. cinnamomi, $P$. parasitica and $P$. palmivora were grown on $\mathrm{V}-8$ agarose medium for $6 \mathrm{~d}$ at $24{ }^{\circ} \mathrm{C}$. This medium consisted of distilled water, $10 \%(\mathrm{v} / \mathrm{v}) \mathrm{V}-8$ juice, $0.02 \%(\mathrm{w} / \mathrm{v}) \mathrm{CaCO}_{3}$ and $0.8 \%(\mathrm{w} / \mathrm{v})$ agarose (SeaKem HGT-P Agarose; Maine Colloids, Rockland, Maine, U.S.A.) which is used as a solidifying agent. A piece of $A^{2}$ mating type culture $(15 \times 10 \times 3 \mathrm{~mm})$ in the centre of a Petri plate $(100 \times 15 \mathrm{~mm})$ was covered with a polycarbonate membrane (CPR, 0.2 $\mu \mathrm{m}, 90 \mathrm{~mm}$ diam.; Nuclepore Corporation, Pleasanton, California, U.S.A.) and paired with an $\mathrm{A}^{1}$ isolate of the same size on the opposite side 
Table 1. Induction of oospore formation by diffusible sex hormones originating in opposite mating type among isolates of $P$. cinnamomi $(P c i), P$. parasitica (Par) and P. palmivora $(P a l)$

\begin{tabular}{ccc}
\multicolumn{2}{c}{ Combination* } \\
\hline $\mathrm{A}^{1}$ & $\times$ & $\begin{array}{c}\mathrm{A}^{2} \\
\text { (Top) }\end{array}$ \\
Pci & Pci \\
Par & Pci \\
Pal & Pci \\
Pci & Par \\
Par & Par \\
Pal & Par \\
Pci & Pal \\
Par & Pal \\
Pal & Pal
\end{tabular}

\begin{tabular}{rr}
\multicolumn{2}{c}{ Oospores (no. $\mathrm{cm}^{-2}$ ) } \\
$\mathrm{A}^{1}$ & $\mathrm{~A}^{2}$ \\
5 & \\
6122 & 0 \\
18 & 0 \\
216 & 0 \\
16837 & 1633 \\
21224 & 469 \\
0 & 830 \\
3265 & 27 \\
563 & 61 \\
& 28
\end{tabular}

* Paired isolates were separated by interposed polycarbonate membranes. The isolates used were UCR 97 (Pci A $)$, 64F (Pci A $)$, P991 (Par A $)$, P731 (Par A $\left.{ }^{2}\right)$, P611 (Pal A $\left.{ }^{1}\right)$ and P255 (Pal A $\left.{ }^{2}\right)$.

Table 2. Effect of age on production of sex hormones by paired isolates of $P$. cinnamomi (Pci), P . parasitica (Par) and P. palmivora (Pal)

\begin{tabular}{|c|c|c|c|}
\hline \multicolumn{2}{|c|}{ Age combination* } & \multicolumn{2}{|c|}{ Oospores (no. $\mathrm{cm}^{-2}$ ) } \\
\hline $\begin{array}{c}A^{1} \\
\text { (Top) }\end{array}$ & $\times \quad \begin{array}{c}A^{2} \\
\text { (Bottom) }\end{array}$ & $\mathrm{A}^{1}$ & $\mathrm{~A}^{2}$ \\
\hline $\begin{array}{l}\operatorname{Pci}(Y) \\
\operatorname{Pci}(0)\end{array}$ & $\begin{array}{l}\text { Pci (o) } \\
\operatorname{Pci}(Y)\end{array}$ & $\begin{array}{r}0 \\
41\end{array}$ & $\begin{array}{l}8 \\
0\end{array}$ \\
\hline $\begin{array}{l}\text { Par (Y) } \\
\text { Par (o) }\end{array}$ & $\begin{array}{l}\text { Par (o) } \\
\operatorname{Par}(\mathbf{Y})\end{array}$ & $\begin{array}{r}1372 \\
80102\end{array}$ & $\begin{array}{r}1083 \\
0\end{array}$ \\
\hline $\begin{array}{l}\text { Pal (Y) } \\
\text { Pal (o) }\end{array}$ & $\begin{array}{l}\text { Pal (o) } \\
\text { Pal (Y) }\end{array}$ & $\begin{array}{r}181 \\
4592\end{array}$ & $\begin{array}{l}9 \\
0\end{array}$ \\
\hline $\begin{array}{l}\text { Pci (Y) } \\
\text { Pci (o) }\end{array}$ & $\begin{array}{l}\text { Par (o) } \\
\text { Par (Y) }\end{array}$ & $\begin{array}{r}361 \\
2041\end{array}$ & $\begin{array}{r}561 \\
0\end{array}$ \\
\hline $\begin{array}{l}\text { Par (Y) } \\
\text { Par (o) }\end{array}$ & $\begin{array}{l}\text { Pci (o) } \\
\text { Pci (Y) }\end{array}$ & $\begin{array}{r}7 \\
20918\end{array}$ & $\begin{array}{r}22 \\
0\end{array}$ \\
\hline
\end{tabular}

* Paired isolates were separated by interposed polycarbonate membranes. $\mathrm{o}$, Six-d-old culture; Y, newly inoculated culture.

of the membrane. After incubation in a moist chamber for $7 \mathrm{~d}$ at $24{ }^{\circ} \mathrm{C}$ in darkness, the number of oospores produced by each mating type was counted under a microscope. The mycelia of the test fungi did not reach the edge of the membranes, nor did they penetrate the membranes during the incubation period. When only the top or bottom layer was inoculated with a single isolate of the fungi, the opposite layer remained sterile after $7 \mathrm{~d}$ incubation. Sterility was tested by incubating the non-inoculated layers on nutrient agar for $7 \mathrm{~d}$ at $24{ }^{\circ} \mathrm{C}$.

\section{RESULTS AND DISCUSSION}

All isolates except the $\mathrm{A}^{2}$ type of $P$. cinnamomi formed oospores by selfing when they were paired, but separated by membranes, with the opposite mating type of the same or different species (Table 1). All the matings resulted in oospore formation predominantly by one mating type. Similar results were obtained when pairings were made with $\mathrm{A}^{2}$ isolates on top and $\mathrm{A}^{1}$ underneath. No oospores were formed when $\mathrm{A}^{1}$ and $\mathrm{A}^{2}$ isolates of $P$. parasitica were similarly paired with the same mating types of $P$. parasitica, $P$. cinnamomi or $P$. palmivora. In other experiments, $\mathrm{A}^{\mathbf{1}}$ and $\mathrm{A}^{2}$ isolates of $P$. parasitica were paired with autoclaved cultures of opposite mating types of the same species or with live cultures of heterothallic Pythium splendens, but no oospores were observed. 
The membrane matings demonstrate the control of sexual reproduction by substances originating in the opposite mating type and reaching the site of activity by diffusion through the membrane. The sex hormone produced by $\mathrm{A}^{1}$ isolates of Phytophthora (designated hormone $\alpha^{1}$ to differentiate it from hormone $\mathrm{A}^{1}$ of $A$ chlya) can induce sexual reproduction of $\mathrm{A}^{2}$ isolates but not $\mathrm{A}^{1}$ isolates. On the other hand, the sexual reproduction of $\mathrm{A}^{1}$ isolates can only be regulated by hormone $\alpha^{2}$ produced by $\mathrm{A}^{2}$ isolates. The substances produced by Trichoderma (Brasier, 1971; Pratt et al., 1972) and those present in avocado roots (Ho \& Zentmyer, 1977) stimulated oospore formation by $\mathrm{A}^{2}$ but not $\mathrm{A}^{1}$ isolates of Phytophthora; they were therefore similar to hormone $\alpha^{1}$ in action. These results strongly support Ashby's suggestion (1929) of the chemical nature of heterothallism among species of Phytophthora.

When 6-d-old and newly inoculated cultures were paired as described above, it was found that, in general, oospores were produced predominantly by old cultures in both intra- and interspecific pairings (Table 2). $\mathrm{A}^{1}$ isolates also produced more oospores than $\mathrm{A}^{2}$ isolates in paired cultures. The results indicated that young cultures and $\mathrm{A}^{2}$ isolates were better hormone producers, whereas old cultures and $\mathrm{A}^{1}$ isolates were more responsive to hormones.

The demonstration of the regulation of sexual reproduction by hormones in heterothallic species of Phytophthora is mainly due to the use of a polycarbonate membrane instead of cellophane which does not prevent penetration by species of Phytophthora (Brasier, 1972; W. H. Ko, unpublished data). The use of agarose instead of agar also led to the production of increased numbers of oospores. A number of chemicals are inactivated in agar by binding (Ko, Kliejunas \& Shimooka, 1976), and inactivation of chemicals can be minimized or prevented by the use of SeaKem agarose (unpublished data). This method facilitates oospore production by single isolates of heterothallic species of Phytophthora which is important in the identification and genetic studies of this group of fungi.

Journal Series Paper No. 2173 of the Hawaii Agricultural Experiment Station. Supported in part by a grant from the McIntire-Stennis Cooperative Forestry Research Program.

\section{REFERENCES}

APple, J. L. (1959). Sexuality of Phytophthora parasitica var. nicotianae. Phytopathology 49, 37-43.

AshBy, S. F. (1929). Strains and taxonomy of Phytophthora palmivora Butler ( $P$. faberi Maubl). Transactions of the British Mycological Society 14, 18-38.

BRASIER, C. M. (1971). Induction of sexual reproduction in single $\mathrm{A}^{2}$ isolates of Phytophthora species by Trichoderma viride. Nature New Biology 231, 283.

BRASIER, C. M. (1972). Observations on the sexual mechanism in Phytophthora palmivora and related species. Transactions of the British Mycological Society 58, 237-251.

Chang, S. T., Shepherd, C. J. \& Pratt, B. $\mathbf{H}$. (1974). Control of sexuality in Phytophthora cinnamomi. Australian Journal of Botany 22, 669-679.

Galloway, L. D. (1936). Report of the imperial mycologist. Scientific Reports of the Imperial Institute of Agricultural Research, Pusa 1934-1935, 120-130.

HaAsis, F. A. \& Nelson, R. R. (1963). Studies on the biological relationship of species of Phytophthora as measured by oospore formation in intra- and interspecific crosses. Plant Disease Reporter 47, 705-709.

Ho, H. H. \& Zentmyer, G. A. (1977). Morphology of Phytophthora cinnamomi. Mycologia 69, 701713.

Ko, W. H., Kliejunas, J. T. \& Shimooka, J. T. (1976). Effect of agar on inhibition of spore germination by chemicals. Phytopathology 66, 363366.

Kouyeas, V. (1953). On the sexuality of Phytophthora parasitica Dastur. Annales de l'Institut phytopathologique Benaki 7, 40-53.

MaRX, D. H., HaAsis, F. A. \& Nelson, R. R. (1965). Failure of metabolic diffusates to induce oospore formation in Phytophthora cinnamomi. Journal of the Elisha Mitchell Scientific Society 81, 75-76.

MunerJee, M. \& Roy, A. R. (1962). Microbial influence on the formation of oospores in culture by Phytophthora parasitica var. sabdariffae. Phytopathology 52, 583-584.

Pratt, B. H., Sedgley, J. H., Heather, W. A. \& SHEPHERD, C. J. (1972). Oospore production in Phytophthora cinnamomi in the presence of Trichoderma koningii. Australian Journal of Biological Science 25, 861-863.

Savage, E. J., Clayton, C. W., Hunter, J. H., Brennaman, J. A., Laviola, C. \& Gallegly, M. E. (1968). Homothallism, heterothallism, and interspecific hybridization in the genus Phytophthora. Phytopathology 58, 1004-1021. 
W. H. KO

Smoot, J. J., Gough, F. J., Lamey, H. A., EichenMULleR, J. J. \& Gallegly, M. E. (1958). Production and germination of oospores of Phytophthora infestans. Phytopathology 48, 165-171.

StamPS, D. J. (1953). Oospore production in paired cultures of Phytophthora species. Transactions of the British Mycological Society 36, 255-259.

ZENTMYER, G. A. (1952). A substance stimulating sexual reproduction in Phytophthora cinnamomi. Phytopathology 42, 24. 